\title{
Biomass carbon accumulation in aging Japanese cedar plantations in Xitou, central Taiwan
}

\author{
Chih-Hsin Cheng ${ }^{1 *}$, Chih-Yu Hung ${ }^{1}$, Chiou-Peng Chen ${ }^{2}$ and Chuang-Wun Pei ${ }^{2}$
}

\begin{abstract}
Background: Japanese cedar (Chrytomeria japonica D. Don) is an important plantation species in Taiwan and represents 10\% of total plantation area. It was first introduced in 1910 and widely planted in the northern and central mountainous areas of Taiwan. However, a change in forest management from exotic species to native species in 1980 had resulted in few new Japanese cedar plantations being established. Most Japanese cedar plantations are now between 30 and 50 years old and reaching their rotation period. It is of interest to know whether these plantations could be viable for future carbon sequestration through the accumulations of stand carbon stocks. Twelve even-aged Japanese cedar stands along a stand age gradient from 37 to 93 years were selected in Xitou of central Taiwan. The study aims were to investigate the basic stand characteristics and biomass carbon stock in current Japanese cedar stands, and determine the relationships among stand characteristics, tree biomass carbon, and stand age.

Results: Our results indicate that existing Japanese cedar plantations are still developing and their live tree biomass carbon continues to accumulate. At stands with a stand age of 90 years, tree density, canopy height, mean diameter at breast height, basal area, and live tree biomass carbon stocks reach to nearly 430 tree ha ${ }^{-1}, 27 \mathrm{~m}, 48$ $\mathrm{cm}, 82 \mathrm{~m}^{2} \mathrm{ha}^{-1}$ and $300 \mathrm{Mg} \mathrm{Cha}^{-1}$, respectively.

Conclusions: Therefore, with no harvesting, current Japanese cedar plantations provide a carbon sink by storing carbon in tree biomass.
\end{abstract}

Keywords: Biomass carbon stocks; Ecosystem carbon stocks; Japanese cedar; Mistcherlich model; Stand age

\section{Background}

Carbon (hereafter denoted by "C") pools and fluxes are receiving increased attention as important factors in global climate change. Forest ecosystems are the primary terrestrial actors in atmospheric $\mathrm{CO}_{2}$ uptake and store two-thirds of terrestrial C stocks (Bonan, 2008). Enhancing forest C sequestration as well as the reducing emissions from deforestation and forest degradation has therefore been suggested as an effective means of curbing elevated atmospheric $\mathrm{CO}_{2}$ level and mitigating global warming (IPCC 2003, 2006).

The potential for forest $C$ sequestration is a dynamics process and depends on the climatic conditions, species composition, forest age, and management practices (Goodale et al., 2002; Pan et al., 2011). Thus, a well-defined

\footnotetext{
* Correspondence: chengch@ntu.edu.tw

'School of Forestry and Resource Conservation, National Taiwan University, Taipei, Taiwan

Full list of author information is available at the end of the article
}

model for estimating forest $C$ sequestration is needed that would enable policymakers to develop comprehensive management programs. However, existing studies focus on temperate forest (Fukuda et al., 2003; Kaipainen et al. 2004). Lack of information in tropical or subtropical forests makes the estimation of forest $\mathrm{C}$ inventories and growth dynamics, including those in Taiwan, particularly difficult.

Japanese cedar (Chrytomeria japonica D. Don) is one of the most important plantation species in Taiwan, representing $10 \%$ of the total plantation area (Forestry Bureau, 1994). It was first introduced in Xitou in 1910. Due to the robust growth performance and the suitable climatic and soil properties (Young, 1975), Japanese cedar was commercially grown over wide areas in the northern and central mountainous areas of Taiwan. The establishment of Japanese cedar plantations reached its peak between 1950 and 1980, but dramatically declined when the focus of national forest management policy shifted from planting exotic species (e.g., Japanese cedar) to native species in 1980. Current 
stand age for most Japanese cedar plantations in Taiwan ranges between 30 and 50 years and reaches or even exceeds their normal rotation period (40-45 years; Wang 1977). This situation has been effectuated partly by a ban on logging in natural forests, which began in 1990, and partly by unfavorable economics in the cedar industry that led to reductions in harvesting. Because the old plantation forests have generally been thought as a carbonneutral state (Odum, 1969), it is of interest to quantify if the "aging" processes of the current Japanese cedar plantations could be able for future $\mathrm{C}$ accumulation.

Previous studies on Japanese cedar plantations in Taiwan have emphasized biomass $C$ stocks within the rotation period, with the result that little is known on stand characteristics development and biomass C stocks in "old" stands over 50 years of age (Young, 1975; Wang 1977). In this study, twelve even-aged Japanese cedar stands along a stand age gradient from 37 to 93 years were selected. The immediate aims were to (1) investigate the basic stand characteristics of tree density, mean diameter at breast height (DBH), basal area (BA) and canopy height and biomass $\mathrm{C}$ stocks in current Japanese cedar stands, and (2) determine the relationships among stand characteristics, tree biomass $\mathrm{C}$, and stand age. The broader aim was to evaluate comprehensively whether Japanese cedar plantations grow beyond the normal rotation age and could be viable for future carbon sequestration through the accumulations of stand carbon stocks. In addition to live tree biomass $\mathrm{C}$ stocks, carbon pools in understory vegetation, forest floor, woody debris and soil organic $\mathrm{C}$ were also investigated in four of the studied stands.

\section{Methods}

\section{Study site}

The study was conducted in the National Taiwan University Experimental Forest in Xitou, central Taiwan $\left(23^{\circ} 40^{\prime} \mathrm{N}, 120^{\circ}\right.$ $\left.47^{\prime} \mathrm{E}\right)$. The mean annual temperature over the last 30 years is $16.6{ }^{\circ} \mathrm{C}$ and the mean annual precipitation is $2,635 \mathrm{~mm}$. Both climatic parameters are shown to be suitable for Japanese cedar (Orwa et al., 2009). The soils, classified as Inceptisols, have developed on the sandstone, siltstone and shale (Chen and Chiang, 1996).

Over the past 100 years, most natural broadleaf forest areas in the Xitou district were replaced by either coniferous or Moso bamboo (Phyllostachys pubescens) plantations. Japanese cedar was the most common coniferous species early on, but after the management shift to native species in 1980 this began to be replaced by the Taiwan red cypress (Chamaecyparis formosensis Matsum.), China fir (Cunninghamia lanceolata), and Taiwania (Taiwania crytomerioides). The total area of Japanese cedar plantations in Xitou is 325 ha, comprising 36\% of all coniferous plantations by area, and stand age ranged mainly between 40 and 90 years.
The study design consisted of 12 even-aged Japanese cedar stands along a stand age gradient from 37 to 93 years (Table 1). Seven of the selected stands (CJ20, CJ33, CJ41, CJ46, CJ50, CJ62, and CJ73; the numerical values indicate the year of planting) had been thinned, pruned, and weeded under typical forest management practices in Xitou. Five of the selected stands (Xitoufu, Xitoufu 3000, Xitoufu 5400, Xitou 3000, and Kadota; the numerical values indicate the planting density per hectare) were the permanent plots purposely established for the longterm growth monitoring. The stand area in the group of 7 ranged between 2.3 to 17.3 ha, whereas the 5 permanent plots were between 0.1 and 0.15 ha (Table 1). For the 7 selected stands, 3 replicated $20 \mathrm{~m} \times 20 \mathrm{~m}$ subplots were established and tree density $\left(\# \mathrm{ha}^{-1}\right), \mathrm{DBH}(\mathrm{cm}), \mathrm{BA}$ $\left(\mathrm{m}^{2} \mathrm{ha}^{-1}\right)$, and canopy height $(\mathrm{m})$ were measured. Diameter at breast height was measured using calipers and the arithmetic mean was calculated to represent the mean DBH at each survey stand. Canopy height was determined with a laser distance meter (Leica Disto D8, Heerbrugg, Switzerland) and was the mean height of 15-20 dominant trees. The BA for the survey stand was calculated from the sum of BA of each tree inside the plot and divided by plot area. For the permanent plots, tree density, DBH, BA, and canopy height for each tree was recorded every 5-10 years (NTU Experimental Forest, 2010). Both the latest and long-term census data were used in the study.

\section{Live tree biomass $\mathrm{C}$ stocks estimation}

The live tree biomass $C$ stocks for each stand was calculated by summing the individual stems within the plot, as illustrated in equation (1).

$$
\begin{aligned}
& \text { Live treebiomassC }\left(\mathrm{MgCh}^{-1}\right) \\
& =(\mathrm{WV} \times \rho \times \mathrm{EF} \times \mathrm{CF}) / \mathrm{A}
\end{aligned}
$$

where WV is stem wood volume $\left(\mathrm{m}^{3}\right) ; \rho$ is basic wood density $\left(\mathrm{Mg} \mathrm{m}^{-3}\right)$; EF is an expansion factor converted from stem biomass to whole tree biomass in the stem, foliage, branches and roots $\left(\mathrm{Mg} \mathrm{Mg}^{-1}\right)$; $\mathrm{CF}$ is carbon fraction of biomass (\%); and A is plot size (ha).

The stem wood volume of individual trees was estimated by using an allometric equation established in the NTU Experimental Forest from 587 trees with ages from 10 to 59 years (Young, 1975).

$$
\begin{aligned}
\mathrm{H}= & 3.4842 \times(\mathrm{DBH})^{0.5228}+1.3 \\
\log \mathrm{V}= & -4.193148+0.9333828 \\
& \times \log \left(\mathrm{DBH}^{2} \times \mathrm{H}\right)
\end{aligned}
$$

where $\mathrm{H}$ is the tree height $(\mathrm{m})$; $\mathrm{DBH}$ is the diameter at breast height $(\mathrm{cm})$; and V is the stem volume $\left(\mathrm{m}^{3}\right)$. Stem wood volume was then multiplied by the basic stem 
Table 1 Stand characteristics and live tree biomass carbon stocks of 12 selected even-aged Japanese cedar stands in Xitou, central Taiwan

\begin{tabular}{|c|c|c|c|c|c|c|c|c|c|c|}
\hline & $\begin{array}{l}\text { Stand } \\
\text { age }\end{array}$ & $\begin{array}{l}\text { Altitude } \\
(\mathrm{m})\end{array}$ & $\begin{array}{l}\text { Stand/plot } \\
\text { area (ha) }\end{array}$ & $\begin{array}{l}\text { Density } \\
\left(\text { no ha }^{-1}\right)\end{array}$ & $\begin{array}{l}\text { Mean } \\
\text { DBH }(\mathrm{cm})\end{array}$ & $\begin{array}{l}\text { Canopy } \\
\text { height (m) }\end{array}$ & $\begin{array}{l}\text { BA } \\
\left(m^{2} h a^{-1}\right)\end{array}$ & $\begin{array}{l}\text { Volume } \\
\left(\mathrm{m}^{3} \mathrm{ha}^{-1}\right)\end{array}$ & $\begin{array}{l}\text { Tree biomass C } \\
\left(\mathrm{Mg} \mathrm{C} \mathrm{ha-1)}^{-1}\right.\end{array}$ & $\begin{array}{l}\text { Thinning } \\
\text { activities }\end{array}$ \\
\hline \multicolumn{11}{|l|}{ Typical stands } \\
\hline CJ73 & 37 & 1370 & 6.3 & $1358(162)^{a}$ & $23.1(0.4)$ & 20.8 & $59.7(4.0)$ & $520(34)$ & $165(10)$ & - \\
\hline CJ62 & 49 & 1250 & 3.8 & $825(95)$ & 28.1(1.3) & 24.0 & $58.1(1.5)$ & $516(10)$ & $163(3)$ & 1990 \\
\hline CJ50 & 60 & 1250 & 16.1 & $617(8)$ & $35.3(1.0)$ & 26.0 & $63.7(4.4)$ & $638(54)$ & $203(16)$ & 1974, 1992 \\
\hline CJ46 & 64 & 1200 & 7.5 & $717(17)$ & $36.5(0.6)$ & 27.0 & $80.7(2.9)$ & $828(34)$ & $262(10)$ & 1960, 1968 \\
\hline CJ41 & 69 & 1150 & 2.3 & $658(36)$ & $33.9(1.1)$ & 24.1 & $64.0(9.2)$ & $678(68)$ & $203(20)$ & 1959, 1963 \\
\hline CJ33 & 77 & 1250 & 10.3 & $685(8)$ & $40.8(0.5)$ & 30.8 & $85.3(2.3)$ & $923(10)$ & $293(3)$ & 1959,1962 \\
\hline CJ20 & 90 & 1150 & 3.0 & $408(22)$ & $48.6(1.2)$ & 29.0 & 77.9 (5.88) & $858(71)$ & $272(21)$ & 1933, 1959 \\
\hline \multicolumn{11}{|c|}{ Permanent plots } \\
\hline Xitoufu & 73 & 1200 & 0.15 & 558 & 42.2 & 28.3 & 81.5 & 862 & 274 & 1928,1930 \\
\hline Xitoufu 3000 & 81 & 1270 & 0.07 & 648 & 40.6 & 27.3 & 89.9 & 953 & 303 & - \\
\hline Xitoufu 5400 & 81 & 1270 & 0.07 & 538 & 39.5 & 28.1 & 69.8 & 729 & 233 & - \\
\hline Xitou 3000 & 95 & 1200 & 0.13 & 397 & 48.8 & 24.5 & 78.1 & 868 & 277 & 1928,1930 \\
\hline Kadota & 93 & 1100 & 0.15 & 471 & 48.5 & 25.6 & 90.7 & 1007 & 320 & 1928,1930 \\
\hline
\end{tabular}

${ }^{a}$ Numbers in parentheses indicate standard error $(n=3)$.

density to estimate stem biomass. A recently reported basic wood density value of $0.416 \mathrm{Mg} \mathrm{m}^{-3}$ for Japanese cedar in Taiwan was applied (Forest Bureau, 2010). The whole tree biomass in stem, branches, foliage, and roots was estimated by multiplying stem biomass by EF. The EF values for Japanese cedar were calculated from previous studies and are shown in Figure 1. The EFs decreased with increasing age and leveled off at 1.545 when stand age exceeds 30 years. Therefore, a constant EF value of 1.545 was used to calculate the whole tree biomass for all 12 stands in this study. Total biomass was then converted into the carbon weight by multiplying CF, which in this study was taken to be $49.5 \%$ (Lin et al., 2002). The obtained EF value was comparable to that for Japanese cedar plantations in Japan (1.54 for stands with stand age older than 40 years; Fukuda et al., 2003), whereas the basic stem density was higher than the average basic density in Japan $\left(0.319 \mathrm{Mg} \mathrm{m}^{-3}\right.$; Fukuda et al., 2003). The basic density of Japanese cedar in Taiwan had been reported to vary from 0.302 to $0.442 \mathrm{Mg} \mathrm{m}^{-3}$ (Ma et al., 1992; Lin, 2006; Forest Bureau, 2010), while this higher mean basic density in the recent survey is probably due to the use of tree samples with old ages (Kennedy, 1995).

\section{Carbon pools in understory vegetation, dead organic matter, and soil organic matter}

In addition to $\mathrm{C}$ pools in living tree biomass, carbon pools in understory vegetation biomass, forest floor, woody debris, and soil organic matter (IPCC, 2006); Peichl and Afrain, 2006) were also estimated in the stands of CJ20, CJ50, CJ58, and CJ73. These C pools were sampled from the three $20 \times 20 \mathrm{~m}$ subplots as well. The understory vegetation was mainly composed of Elatostema platyphylloide, Angiopteris lygodiifolia, Alocasia macrorrhiza and Urtica thunbergiana. Their $\mathrm{C}$ pools were determined by clipping understory biomass at ground level in two randomly-established $2 \mathrm{~m} \times 2 \mathrm{~m}$ quadrats. Forest floor was determined by gathering all organic material lying on the forest floor within $0.52 \mathrm{~m} \times 0.52 \mathrm{~m}$ quadrat followed by the clipping of understory biomass. Understory biomass and forest floor samples were oven-dried at $65^{\circ} \mathrm{C}$ to constant mass and weighed. Carbon stocks were

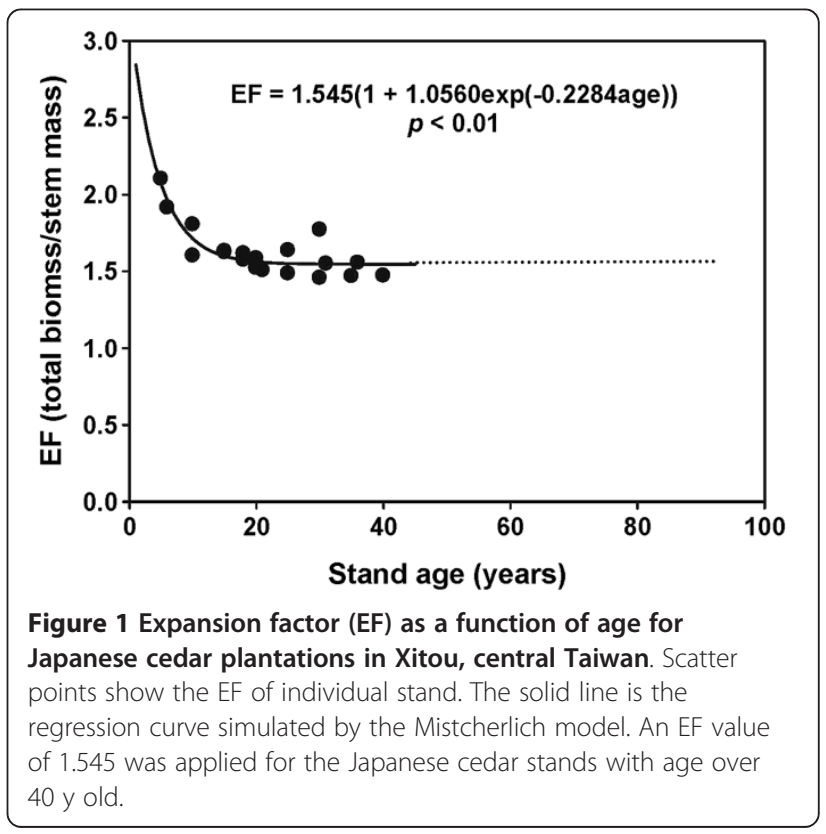


calculated by multiplying the dry weight by $\mathrm{C}$ fraction. Woody debris ( $>2.5 \mathrm{~cm}$ in diameter; $<2.5 \mathrm{~cm}$ in diameter was considered forest floor) was estimated using the line intersect sampling method. An intersect line was run down the length of a $1 \mathrm{~m} \times 20 \mathrm{~m}$. All woody debris inside this area was collected. Pieces extending outside the area were cut at the boundaries. All debris were oven-dried at $65^{\circ} \mathrm{C}$ to constant mass and weighed. A small amount was mixed and ground to measure the $\mathrm{C}$ fraction. The $\mathrm{C}$ pools in woody debris were estimated by multiplying the dry weight by $\mathrm{C}$ fraction.

Soil samples were collected using a soil corer $6.37 \mathrm{~cm}$ in diameter. Samples were taken at depths of $0-10 \mathrm{~cm}$, $10-20 \mathrm{~cm}$, and $20-30 \mathrm{~cm}$, with sample for each depth range being composited from at least 6 sampling locations within each subplot. Soil samples were air-dried and ground to pass through a $2 \mathrm{~mm}$ sieve. A subsample of soils was finely ground using a ball grinder (Oscillating Mill MM400 by Retsch, Newtown, PA, USA) for C analysis. Bulk density was determined using the core method. Stone content was assessed based on field observations based on the menu of the Munsell Soil Color Chart. Soil C stocks were calculated by multiplying $\mathrm{C}$ concentration by bulk density, stone contents, and soil horizon thickness.

In this study, the $C$ fraction for understory vegetation biomass, forest floor, woody debris, and soil organic carbon were determined using an elemental analyzer (Perkin Elmer 2400 CHN; Perkin Elmer, Norwalk, CT, USA).

\section{Age-related stand characteristics development and live tree biomass $\mathrm{C}$ accumulation}

Live tree biomass $\mathrm{C}$ stocks and stand characteristics of tree density, mean DBH, canopy height and basal area are useful indices of stand development (Fain et al., 1994). In this study, the effect of stand age on these values was determined. We first combined the latest census data from the 5 permanent plots with that from 7 selected stands to represent the stand-level growth of Japanese cedar plantations covering with spatial variation. In addition, we assembled data from previous studies (Additional file 1: Table S1) with the current results to model the age-related changes of stand characteristics and live tree biomass $C$ stocks. However, the values of $\mathrm{BA}$ and live tree biomass were not provided in some previous studies and simply calculated based on the mean DBH and tree density. Thus, a general age-related trend was focused here rather than the discussion for the interplay among parameters because of the slight differences in the calculations/estimations. Second, the long-term monitoring data from each permanent plot were used to assess trends in stand characteristics development and live tree biomass $\mathrm{C}$ stocks accumulation inside each permanent plot.

Stand characteristics and live tree biomass $C$ stocks as functions of stand age were calculated with a common Mitscherlich function (Fukuda et al., 2003) by using SAS version 9.2 as follows:

$$
\begin{aligned}
& \text { Living tree biomass } C \text { or stand characteristics } \\
& \quad=\mathrm{m}_{1} \times\left(1-\mathrm{m}_{2} \times \exp \left(-\mathrm{m}_{3} \times \text { stand age }\right)\right)
\end{aligned}
$$

where $\mathrm{m}_{1}$ is the asymptote, the maximum/minimum number of stand characteristics of tree density, mean $\mathrm{DBH}$, canopy height and basal area or amount of living tree biomass $C$; and $m_{2}$ and $m_{3}$ are parameters of the Mitscherlich model.

\section{Results}

Stand characteristics and live tree biomass $\mathrm{C}$ stocks

Stand characteristics (tree density, mean DBH, BA, and canopy height) and live tree biomass $\mathrm{C}$ stocks for the 12 selected Japanese cedar stands are listed in Table 1. The highest tree density $\left(1,358\right.$ trees $\left.\mathrm{ha}^{-1}\right)$ was found in CJ73, where no thinning activity had occurred. Stand tree density declined with stand age and reached its lowest point at approximately 430 trees $\mathrm{ha}^{-1}$ for the 90 -year-old stands. By contrast, the values for stand characteristics, including canopy height, mean DBH, and BA, increased with stand age. Despite decreasing tree density, the increases in DBH and BA caused the living tree biomass to increase. Live tree biomass $C$ stocks for the 12 selected stands ranged from 165 to $320 \mathrm{Mg} \mathrm{C}^{-1}$ and tended to increase with stand age. For stands at 90 years of age, canopy height, mean DBH, BA, and tree biomass C stocks were nearly $27 \mathrm{~m}, 48 \mathrm{~cm}, 82 \mathrm{~m}^{2} \mathrm{ha}^{-1}$ and 300 $\mathrm{Mg} \mathrm{C} \mathrm{ha}^{-1}$, respectively.

Using data from previous studies, general age-related patterns in tree density, mean $\mathrm{DBH}, \mathrm{BA}$, and live tree biomass $\mathrm{C}$ stocks were determined (Figure 2). Stand age appeared to have a direct effect on stand characteristics and live tree biomass $C$ stocks. Stand tree density, canopy height and BA took 60 years to reach $90 \%$ minimum/ maximum values, whereas mean $\mathrm{DBH}$ and live tree biomass $C$ stocks remained below the maximum values at the stand age of 90 years. These relationships between stand characteristics and tree biomass stocks and stand age were well regressed by the Mistcherlich model, which yielded potential values of 360 trees $^{-1}, 67 \mathrm{~cm}, 30 \mathrm{~m}, 77$ $\mathrm{m}^{2} \mathrm{ha}^{-1}$, and $541 \mathrm{Mg} \mathrm{C}^{-1}$ for tree density, mean DBH, canopy height, $\mathrm{BA}$, and live tree biomass $\mathrm{C}$ stocks, respectively (Figure 2).

The temporal trends in stand characteristics and live tree biomass $\mathrm{C}$ stocks from the permanent plots were similar to the trends observed in the spatial data set, in which tree density decreased with stand age, whereas 

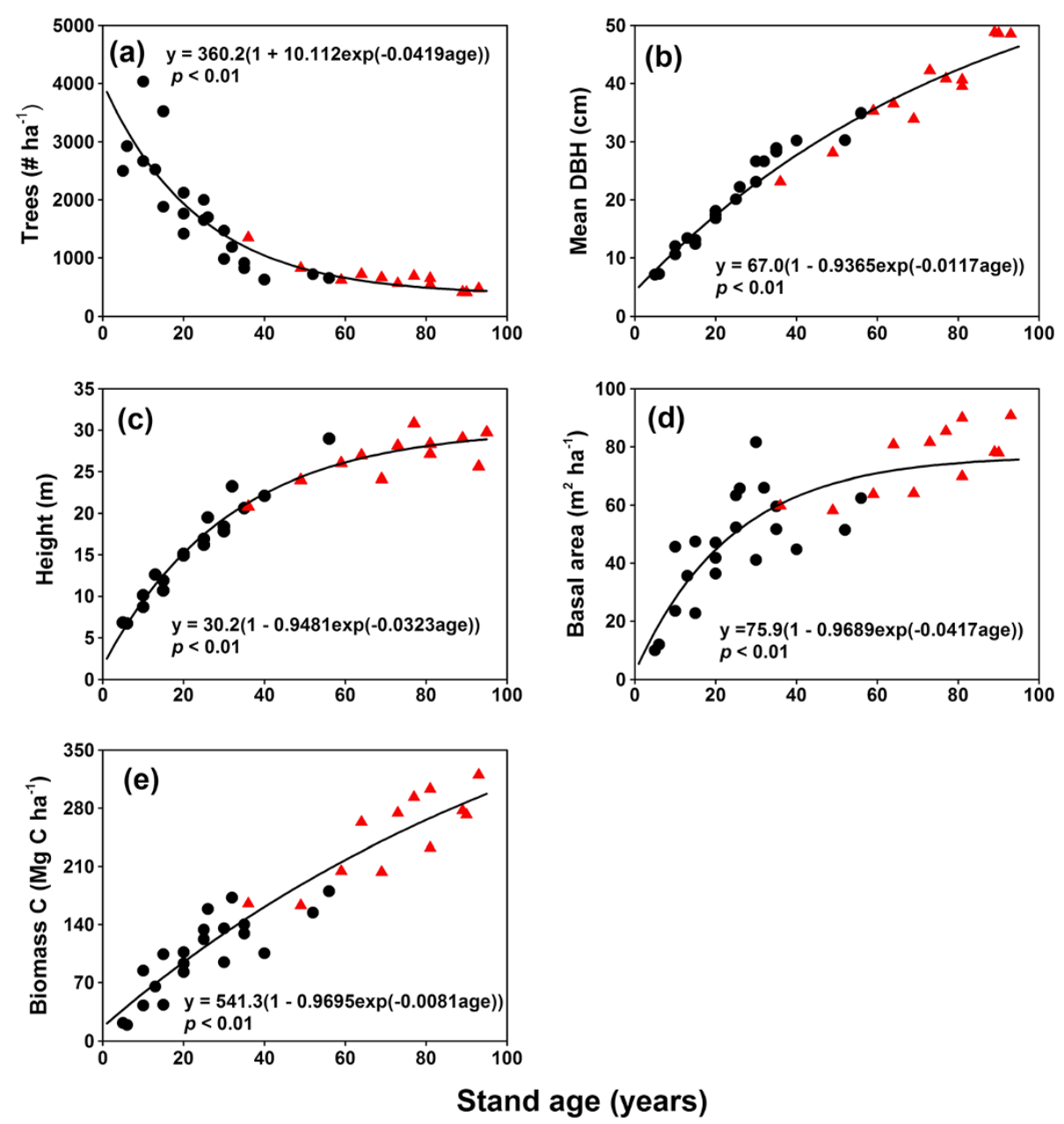

Figure 2 Age-related stand characteristics and live tree biomass C stocks for the Japanese cedar plantations in Xitou, central Taiwan. Each point represents a single stand. The solid line is the regression curve simulated by the Misterchlich model. Black circles are data from previous studies. Red triangles stand for the 12 selected stands in this study. (a) tree density, (b) mean DBH, (c) canopy height, (d) basal area, and (e) live tree biomass $C$ stocks.

mean DBH, canopy height, BA, and live tree biomass $\mathrm{C}$ stocks increased (Figure 3). Thus, both spatial and spectral data sets suggest that live tree biomass $C$ stocks can continue to accumulate in Japanese cedar stands over 90 years old.

\section{Carbon pools in understory vegetation, dead organic} matter and soil organic matter

Carbon pools in wood debris, forest floor, and understory vegetation for 4 selected stands ranged from 0.28 to 6.12 , from 1.95 to 3.21 , and from 1.6 to $2.8 \mathrm{Mg} \mathrm{C}$ ha $^{-1}$, respectively (Figure 4). Compared to tree biomass C stocks, these carbon pools were proportionally small $(<5 \%)$. In addition, these $C$ pools varied among stands and showed no apparent age-related trends (Figure 4). The $\mathrm{C}$ pools in the soil organic matter to a depth of 30 $\mathrm{cm}$ ranged between 83 and $148 \mathrm{Mg} \mathrm{C} \mathrm{ha}{ }^{-1}$, and were comparable with $\mathrm{C}$ stocks in the live tree biomass. The
$\mathrm{C}$ pools in the soil organic matter and tree biomass together comprised more than $95 \%$ of ecosystem C stocks. Again, no clear relationship was found between stand age and soil organic $C$ at the $0-30 \mathrm{~cm}$ depth range, or between stand age and soil organic $\mathrm{C}$ in individual horizons of $0-10,10-20$, and $20-30 \mathrm{~cm}$ (data not shown).

\section{Discussion}

\section{Relationship of $\mathrm{C}$ stocks to stand age}

Our results derived from both spatial and temporal data sets indicate that the stand characteristics of tree density, mean $\mathrm{DBH}$, canopy height and basal area for present Japanese cedar plantations in Xitou are still developing and that live tree biomass $\mathrm{C}$ stocks are also continually accumulating. These results are in agreement with the findings of studies of Japanese cedar plantations in Japan that found biomass $\mathrm{C}$ continued to accumulate after 90 years of age (Fukuda et al., 2003; Takeuchi, 2005; 

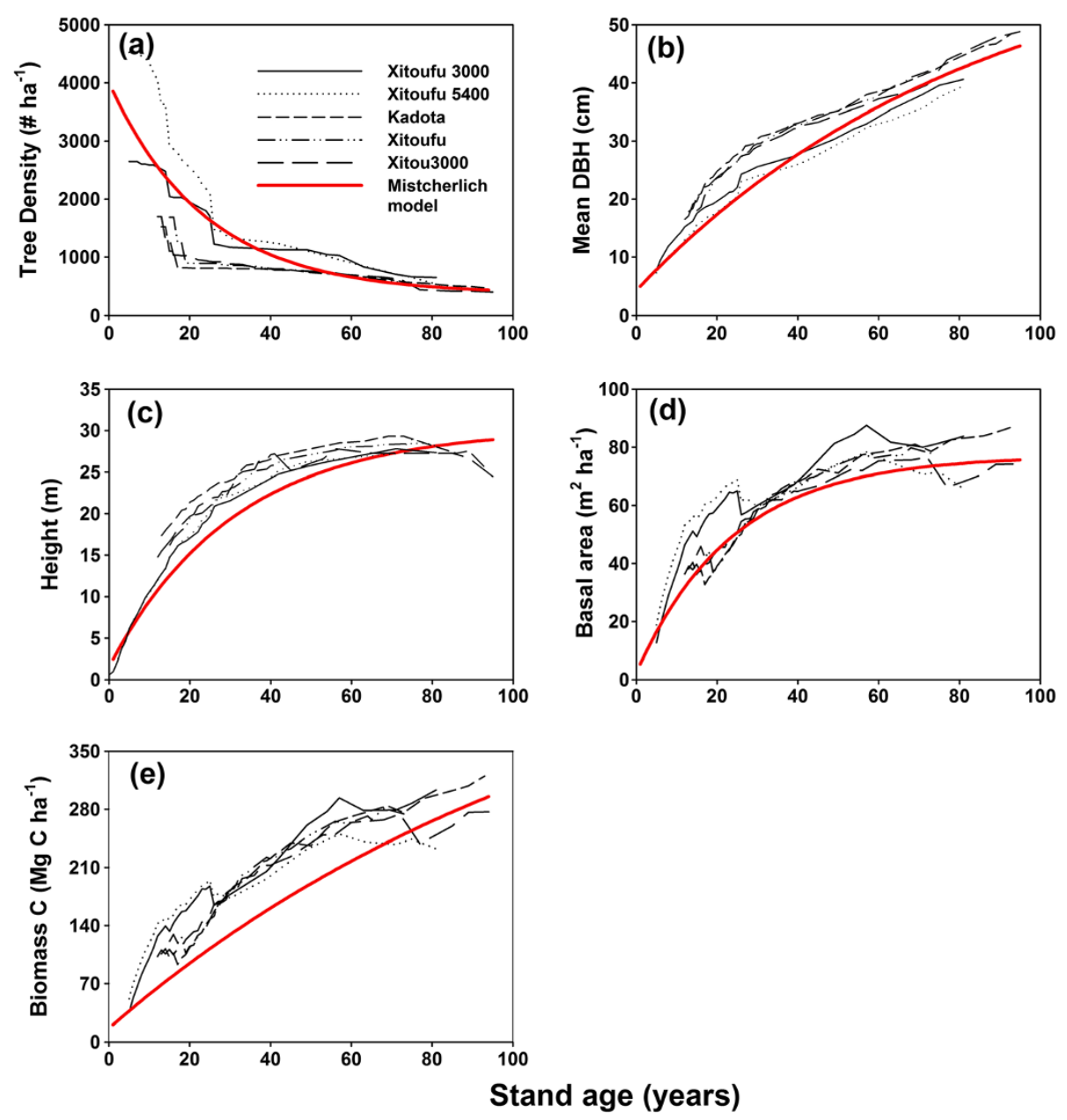

Figure 3 Age-related stand characteristic and live tree biomass $C$ stocks for Japanese cedar plantations in five permanent plots in Xitou, central Taiwan. Each black line represents an individual permanent plot. The red line is the Mistcherlich curve simulated from the spatial data set. (a) tree density, (b) mean DBH, (c) canopy height, (d) basal area, and (e) live tree biomass $\mathrm{C}$ stocks.

Sasaki and Kim, 2009). Many studies from other regions and on other species have similarly shown living tree biomass $\mathrm{C}$ stocks accumulating in stand scale that are either over 90 years old (Law et al., 2003; Pregitzer and Euskirchen, 2004) or behind their normal rotation period (Kaipainen et al. 2004; Foley et al., 2009). In contrast, some studies indicate that live tree biomass $\mathrm{C}$ stocks may begin leveling off at 90 years (Shoch et al., 2009; Bradford and Kastendick, 2010). Our results disprove previous ideas that some silviculturiests assumed the increments of Japanese cedar stands becoming "stagnated" behind 60 years in Taiwan (Liu et al., 1977; Liu and Horng, 1978), wherein the old stands with age over 60 years were not included in those studies. In addition, the results of the increase in DBH with stand age provide the direct effect on increasing live tree biomass $C$ stocks with stand age, even though the tree density, canopy height and BA are leveled off after stand age behind 60 years. These linkages between stand characteristics of tree density, mean DBH, canopy height and basal area and living tree biomass $\mathrm{C}$ truly improve our knowledge of the prior studies.

Live tree biomass $\mathrm{C}$ stocks of old-growth Japanese cedar stands in this study fell within the range of $C$ stocks values for old-growth stands in Japan, which have been variously estimated at $131-322 \mathrm{Mg} \mathrm{C}^{-1}$ in 77 - 126-year-old stands (converted at root/total biomass ratio at 0.20 and carbon fraction at 0.5; Enoki et al., 2010); 234-459 Mg C ha $^{-1}$ in 94-year-old stand (Masaki et al., 2006), and 219$415 \mathrm{Mg} \mathrm{C} \mathrm{ha}^{-1}$ in 101- 200-year-old stands (converted at basic stem density at 0.319 , carbon fraction at 0.5 , and $\mathrm{EF}$ at 1.54; Takeuchi, 2005). Fukuda et al. (2003) estimated live tree biomass $C$ stocks for Japanese cedar plantations across Japan and proposed a range of $162-230 \mathrm{Mg} \mathrm{C} \mathrm{ha}^{-1}$ at 90 year of age, which is less than our estimation. The difference between our estimation and that of Fukuda et al. (2003) may be due to the different basic wood density values used: $0.416 \mathrm{Mg} \mathrm{m}^{-3}$ in this study compared to $0.319 \mathrm{Mg} \mathrm{m}^{-3}$ in Japan. The higher tree biomass $\mathrm{C}$ in 

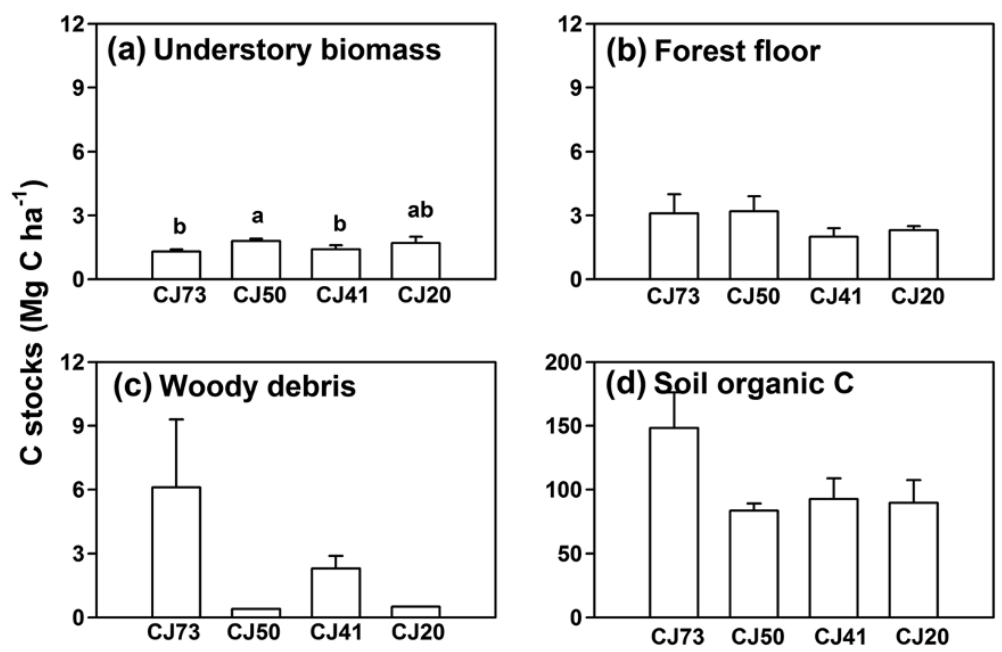

Figure 4 Carbon stocks in different pools for four Japanese cedar stands with stand ages between $\mathbf{4 0}$ and 90 years (a) understory vegetation, (b) forest floor, (c) woody debris, and (d) soil organic matter. Error bars are standard error of the mean. The different lowercase letters indicate significant differences between stands.

Taiwan is in part because the trees are thinned less than there in Japan (Chiba, 1998). Chiba (1998) suggested that reducing thinning may help maintain stand biomass $\mathrm{C}$ density.

Although biomass $\mathrm{C}$ stocks have the highest $\mathrm{C}$ density in older stands, the annual biomass $\mathrm{C}$ increment calculated from the Mistcherlich model (Figure 2(e)) decreases with stand age from $3.35 \mathrm{MgC} \mathrm{ha}^{-1}$ year $^{-1}$ at 30 years of age to 2.65 and $2.06 \mathrm{MgC} \mathrm{ha}^{-1}$ year $^{-1}$ at 60 and 90 years, respectively. This decline in annual biomass $\mathrm{C}$ accumulation in older stands is similar to that reported in other studies (Binkley et al., 2002; Ryan et al., 2004), implying that younger stands have a larger $C$ sink capacity. The mean value of annual biomass $\mathrm{C}$ increments for Japanese cedar plantations in Xitou is higher than the mean values for Japanese cedar plantations in Japan (2.1 Mg C ha' Fukuda et al., 2003), but less than those from several specific experimental plots, including a 40-year-old plot in Takayama (4.1 Mg C ha- $\mathrm{yr}^{-1}$; Yashiro et al., 2010) and a 31-year-old and a 71 year-old plot in Tottori (7.0 and 5.4 $\mathrm{Mg} \mathrm{C} \mathrm{ha}{ }^{-1} \mathrm{yr}^{-1}$, respectively; Hosoda, 1999).

In addition to the relationship between tree biomass $\mathrm{C}$ stocks and stand age, changes in stand characteristics of tree density, mean $\mathrm{DBH}$, canopy height and $\mathrm{BA}$, were also manifest. Compared to young stands, old Japanese cedar stands feature the following characteristics: (1) lower tree densities, (2) larger stem DBH distributions across size classes, and (3) higher BA values and greater tree height, yet these two features become asymptotic when stand age exceed 60 years. Some other stand characteristics often found in natural old-growth forests, for example, understory reinitiation and coarse woody debris accumulation (Tyrrell and Crow, 1994), are not present in the older Japanese cedar plantations in Xitou, perhaps because of thinning, weeding or residual log removal that are practiced.

Carbon pools in woody debris, understory vegetation, forest floor, and soil organic matter showed no clear age-related pattern in this study. This is perhaps also because of the stand management operations undertaken in Xitou. In addition, some studies have suggested that over time these components may stabilize at steady-state level (Shutou and Nakane, 2004; Jandl et al., 2007; Nave et al., 2010). For instance, Shutou and Nakane (2004) indicate that $\mathrm{C}$ pools in soil organic matter and forest floor study in Japanese cedar stands level off 40 years after clear-cutting, which is in agreement with our findings that stand aged between 37 and 90 years showed no significant difference with stand age (Figure 4). Because $\mathrm{C}$ pools in understory vegetation, dead organic matter, and soil organic matter do not change in late stages of stand development, most $\mathrm{C}$ sequestration occurs in the live tree biomass $\mathrm{C}$. However, further long-term temporal observation is needed to evaluate the changes of $\mathrm{C}$ stocks in these pools accurately.

\section{Implications}

In this study, the age-related model is established based on the spatial and spectral data sets and covered with a wide range of stand age (6-93 years) and stand number (33 stands in the 325 ha area). We believe that such sampling strategy is adequate to avoid the particular influences from an individual site and provide relevant information to understand the dynamics of stand characteristics and live tree biomass $\mathrm{C}$ stocks for the Japanese cedar plantations in Xitou, central Taiwan. The age-related stand development patterns found in the present study highlight the potential of existing Japanese cedar plantations for future C 
Table 2 Total area and total calculated live tree biomass C stocks and the increments of $C$ stocks in 2012-2022 period for Japanese cedar plantations in Taiwan

\begin{tabular}{|c|c|c|c|}
\hline $\begin{array}{l}\text { Stand age } \\
\text { (years) }\end{array}$ & $\begin{array}{l}\text { Total area } \\
\text { (ha) }\end{array}$ & $\begin{array}{l}\text { Total biomass } C \text { stocks } \\
\left(\times 10^{3} \mathrm{Mg}\right)\end{array}$ & $\begin{array}{l}\Delta \mathrm{C} \text { in } 2022 \\
\left(\times 10^{3} \mathrm{Mg}\right)\end{array}$ \\
\hline$>80$ & 781 & 215 & 15 \\
\hline 70-80 & 3,606 & 906 & 78 \\
\hline $60-70$ & 1,524 & 349 & 36 \\
\hline $50-60$ & 8,201 & 1,657 & 209 \\
\hline 40-50 & 13,150 & 2,245 & 369 \\
\hline $30-40$ & 12,710 & 1,882 & 380 \\
\hline 20-30 & 194 & 24 & 6 \\
\hline$<20$ & 0 & 0 & 0 \\
\hline Total & 40,169 & 7,287 & 1,093 \\
\hline $\begin{array}{l}\text { Area-weighted C } \\
\text { stocks }\end{array}$ & & 182 & 209 \\
\hline$(\mathrm{Mg} \mathrm{Cha-1})$ & & (in 2012) & (in 2022) \\
\hline
\end{tabular}

${ }^{a}$ Calculated equation: $[541.3 \times(1-0.9695 \times \exp (-0.0081 \times$ age $))] \times$ area.

accumulation. Moreover, the research model used here can be expanded to estimate nationwide biomass $\mathrm{C}$ stocks and near-term $\mathrm{C}$ accumulation rates. Live tree biomass $\mathrm{C}$ stocks of Japanese cedar plantations in other areas of Taiwan are shown in Additional file 1: Figure S1. The similarity between the overall trend in those studies and that the trend in Xitou encourages a wider application of the present model. Based on the data from Forestry Bureau (1994), total area of Japanese cedar plantations is around 40,000 ha and its average live tree biomass C stocks that are calculated by the present model is estimated to be $182 \mathrm{Mg} \mathrm{C}^{-1}$. This figure is expected to increase to $209 \mathrm{Mg} \mathrm{C} \mathrm{ha}^{-1}$ by the year of 2022, with an annual biomass $\mathrm{C}$ accumulation of $2.7 \mathrm{Mg} \mathrm{C} \mathrm{ha}{ }^{-1} \mathrm{y}^{-1}$ (Table 2). Net amounts of $C$ sequestration in tree biomass for whole Japanese cedar plantations will be $1.09 \times 10^{6} \mathrm{Mg} \mathrm{C}$ during the period 2012-2022, equal to an annual increase of $1.09 \times 10^{5} \mathrm{Mg} \mathrm{C} \mathrm{y}^{-1}$. With no harvesting, Japanese cedar plantations in Taiwan provide a $\mathrm{C}$ sink by storing carbon in tree biomass. The value of annual $\mathrm{C}$ accumulation in Japanese cedar plantation equals to $13 \%$ of the annual fossil fuel consumption from agriculture sector $\left(8.59 \times 10^{5} \mathrm{Mg} \mathrm{C} \mathrm{y}^{-1}\right.$; Environmental Protection Administration, 2012), but only $0.2 \%$ compared to the whole fossil fuel consumption in Taiwan $\left(6.84 \times 10^{7}\right.$ $\mathrm{Mg} \mathrm{C}^{-1}$, Environmental Protection Administration, 2012).

In addition to the increases in biomass $C$ stocks, the average tree DBH also increases with age (Figure 2b). The increase in tree DBH has been proposed as a mechanism for $\mathrm{C}$ sequestration because a greater $\mathrm{C}$ portion can be allocated into long-lived wood products generated from harvested timber (Kaipainen et al., 2004; Foley et al., 2009). Therefore, ageing process of Japanese cedar plantations may then be a legitimate forest management activity for the reduction of greenhouse gas emissions (IPCC, 2003; Kaipainen et al., 2004; Foley et al., 2009). However, information for quantitative estimation has not been established in Taiwan and further research must be conducted.

Although this study proposes Japanese cedar plantations as sites for $\mathrm{C}$ sequestration, the domestic and industrial demand for timber cannot be ignored. Otherwise, the reduced harvest would have an effect on shifting wood harvest elsewhere or shifting to other products that require more carbon to produce (Gustavsson and Sathre, 2006). The data on stand characteristics development and biomass $\mathrm{C}$ accumulation of Japanese cedar plantations presented here should, therefore, be incorporated with similar data for other species to create a comprehensive database for forestry management in Taiwan.

\section{Conclusion}

Our results indicate that present Japanese cedar plantations in the Xitou area of Taiwan are still developing and that live tree biomass $\mathrm{C}$ stocks continue to accumulate beyond the normal rotation period or even beyond a stand age of 90 years. If Japanese cedar stands are not harvested, they can provide a $\mathrm{C}$ sink by storing carbon in tree biomass. In association with the increases in tree $\mathrm{DBH}$ with stand age, maintaining this ageing process can be a forest management mechanism for the reduction of greenhouse gas emissions.

\section{Additional file}

Additional file 1: Table S1. Previous studies of stand characteristics and live tree biomass $C$ stocks of even-aged Japanese cedar stands in Xitou, central Taiwan. Figure S1. Japanese cedar live tree biomass $C$ stocks in Taiwan.

\section{Competing interests}

The authors declare that they have no competing interests.

\section{Authors' contributions}

$\mathrm{CCH}$ and $\mathrm{CYH}$ planned the study, analyzed the data and developed the paper. CPC and CWP aided the field study and provided input to the manuscript. All authors read and approved the final manuscript.

\section{Acknowledgments}

This research was supported by the National Science Council of Taiwan (Project no. 100-2621-M-002-030-) and the NTU Experimental Forest. We thank Cheng-Yu Lee, Hsin-Show Wonlo, Yin-Ru Lin, Yu-Shung Huang and Chih-Yung Hung for their valuable assistance in the field work.

\section{Author details}

'School of Forestry and Resource Conservation, National Taiwan University, Taipei, Taiwan. ${ }^{2}$ NTU Experimental Forest, National Taiwan University, Nantou, Taiwan.

Received: 12 December 2012 Accepted: 7 October 2013

Published: 3 December 2013

\section{References}

Binkley D, Stape JL, Ryan MG, Barnard HR, Fownes J (2002) Age-related decline in forest ecosystem growth: an individual tree stand-structure hypothesis. Ecosystems 5:58-67 
Bonan GB (2008) Forests and climate change: forcings, feedbacks, and the climate benefits of forests. Science 320:1444-1449

Bradford JB, Kastendick DN (2010) Age-related patterns of forest complexity and carbon storage in pine and aspen-birch ecosystems of northern Minnesota, USA. Can J For Res 40:401-409

Bureau F (1994) Inventory report for public plantations in Forestry Bureau. Forest Bureau, Taipei, Taiwan, p 114 (In Chinese)

Bureau F (2010) Practical manual for silviculture. Forest Bureau, Taipei, Taiwan, p 349 (in Chinese)

Chen XS, Chiang HC (1996) Soil characteristics, genesis, and classification of some forest soils in Taiwan. Proc Int Congr Soils Trop Forest Ecosystem, (3rd Congress on Forest Soils) 1:63-78

Chiba Y (1998) Simulation of $\mathrm{CO}_{2}$ budget and ecological implications of sugi (Cryptomeria japonica) man-made forests in Japan. Ecol Model 111:269-281

Enoki T, Inoue T, Tashiro N, Ishii H (2010) Aboveground productivity of an unsuccessfule 140-year-old Cryptomeria japonica plantation in northern Kyushu. J For Res 16:268-274

Environmental Protection Administration (2012) Toward UNFCCC: Taiwan is willing to contribute global community. Environmental Protection Administration, Executive Yuan, Taiwan. http://unfccc.epa.gov.tw/unfccc/ english/index.html

Fain JJ, Volk TA, Fahey TJ (1994) Years of change in an upland forest in south-central New York: general patterns. Bull Torrey Bot Club 121:130-139

Foley TG, Richter D, Gali CS (2009) Extending rotation age for carbon sequestration: a cross-protocol comparsion of north American forest offsets. For Ecol Manage 259:201-209

Fukuda M, lehara T, Matsumoto M (2003) Carbon stock estimates for sugi and hinoki forests in Japan. For Ecol Manage 184:1-16

Goodale CL, Apps MJ, Birdsey RA, Field CB, Heath LS, Houghton RA, Jenkins JC, Kohlmaier GH, Kurz W, Liu S, Nabuurs GJ, Nilsson S, Shvidenko AZ (2002) Forest carbon sinks in the northern hemisphere. Ecol Appl 12:891-899

Gustavvson L, Sathre R (2006) Variablity in energy and carbon dioxide balance of wood and concrete building materials. Build Environ 41:940-951

Hosoda K (1999) Growth performance of Sugi plantationin Sanin region - a case study at Shinotani Mount experiemental site. Report of the FFPRI Kansai Office No. 41, in Japanese). http://www.fsm.affrc.go.jp/Nenpou/41/p32.html (accessed on 3 May, 2012)

IPCC (2003) Good practice guidance for land use, land use change and forestry. IPCC/IGES, Hayama, Japan. http://www.ipcc-nggip.iges.or.jp/

IPCC (2006) IPCC Guides for national greenhouse gases inventories. Hayama, Japan. http://www.ipcc-nggip.iges.or.jp/public/2006gl/index.html

Jandl R, Lindner M, Vesterdal L, Bauwens B, Bartiz R, Hagedorn F, Johnson DW, Minkkinen K, Byrne KA (2007) How strongly can forest management influence soil carbon sequestration? Geoderma 137:253-268

Kaipainen T, Liski J, Pussinen A, Karjalaine T (2004) Managing carbon sinks by changing rotation length in European forest. Environ Sci Policy 7:205-219

Kennedy RW (1995) Coniferous wood quality in the future: concerns and strategies. Wood Sci Technol 29:321-338

Law BE, Sun OJ, Campbell J, Van Tuyl S, Thornton PE (2003) Changes in carbon storage and fluxes in a chronosequence of ponderosa pine. Glob Chang Biol 9:510-524

Lin SC (2006) Biomass survey for Japanese cedar: reveiwer and perspective. In: Proceeding of 2006 National Conference on Carbon Sequestration. Taipei, Taiwan, pp 130-146

Lin YJ, Liu CP, Lin JC (2002) Measurement of specific gravity and carbon content of important timber species in Taiwan. Taiw J For Sci 17:291-299 (in Chinese)

Liu SC, Horng FW (1978) Growth and yield of Cryptomeria plantation in Taiwan (II)- A-Li-San region. Taiw For Res Insti Bull. No 309 (in Chinese)

Liu SC, Horng FW, Chang LP (1977) Growth and yield of Crypotmeria Plantaion in Taiwan (I)-Wu-Lai and Wen-San working circles. Taiw For Res Insti Bull. No 309 (in Chinese)

Ma TP, Chen CC, Hsiung RC, Hwang CY, Chen SS, Chai SY (1992) The general character of the woods providing for the import commerical use. Forestry Monog, No. 1. Taiw For Res Inst:204 (in Chinese)

Masaki T, Mori S, Kajimoto T, Histuma G, Sawata S, Mori M, Osumi K, Sakurai S, Seki T (2006) Long-term growth analyses of Japanese cedar trees in a plantation: neightborhood competition and persistence of initial growth deviations. J For Res 11:217-225

Nave LE, Vance ED, Swanston CW, Curtis PS (2010) Harvest impacts on soil carbon storage in temperature forests. For Ecol Manag 259:857-866
NTU Experimental Forest (2010) Special issue (I) in long-term experimental sites. National Taiwan University Experimental Forest, Nantou, Taiwan, p 288 (in Chinese)

Odum EP (1969) The strategy of ecosystem development. Science 164:262-270

Orwa C, Mutua A, Kindt R, Jamnadass R, Simons A (2009) Agroforest tree database: a tree reference and selection guide version 4.0. http://www. worldgroforestry.org/af/treedb

Pan Y, Birdsey RA, Fang J, Houghton R, Kauppi PE, Kurz WA, Phillips OL, Shvidenko A, Lewis SL, Canadell JG, Ciais P, Jackson RB, Pacala SW, McGuire AD, Piao S, Rautiainen A, Sitch S, Hayes D (2011) A large and persistent carbon sink in the world's forests. Science 333:988-993

Peichl M, Afrain MA (2006) Above- and belowground ecosystem biomass and carbon pools in an age-sequence of temperate pine plantation forests. Agr Forest Meteorol 140:51-63

Pregitzer KS, Euskirchen ES (2004) Carbon cycling and storage in world forests: Biome patterns related to forest age. Glob Chang Biol 10:2052-2077

Ryan MG, Binkley D, Fownes JH, Giardina CP, Senock RS (2004) An experimental test of the causes of forest growth decline with stand age. Ecol Monoge 74:393-414

Sasaki N, Kim S (2009) Biomass carbon sinks in Japanese forests: 1966-2012. Forestry 82:105-115

Shoch DT, Kaster G, Hohl A, Souter R (2009) Carbon storage of bottmland hardwood afforestation in the lower Mississippi valeey, USA. Wetland 29:535-542

Shutou K, Nakane K (2004) Change in soil carbon cycling for stand development of Japanese cedar (Cryptomeria japonica) plantations following clear-cutting Ecol Res 19:233-244

Takeuchi I (2005) The growth of diamter and stand stem volumes in old man-made Sugi (Cryptomeria japonica) stands. J J.pn For Res 87:394-401 (in Japanese)

Tyrrell LE, Crow TR (1994) Structural characteristics of old-growth hemlockhardwood forests in relation to age. Ecology 75:370-386

Wang $T$ (1977) Tree biomass production in Cryptomeria stands of different age classes. J Agri Assoc China 102:59-76

Yashiro Y, Lee NM, Ohtsuka T, Shizu Y, Saitoh TM, Koizumi H (2010) Biometricbased estimation of net ecosystem production in a mature Japanese cedar (Cryptomeria japonica) plantation beneath a flux tower. J Plant Res 123:363-472

Young YC (1975) Study in the growth and harvest of Japanese cedar in NTU Experimental Forest. NTU Experimental For. Res. Rep.. No 116 (in Chinese)

\section{doi:10.1186/1999-3110-54-60}

Cite this article as: Cheng et al: Biomass carbon accumulation in aging Japanese cedar plantations in Xitou, central Taiwan. Botanical Studies 2013 54:60

\section{Submit your manuscript to a SpringerOpen ${ }^{\circ}$ journal and benefit from:}

- Convenient online submission

- Rigorous peer review

- Immediate publication on acceptance

- Open access: articles freely available online

- High visibility within the field

- Retaining the copyright to your article

Submit your next manuscript at $\boldsymbol{\wedge}$ springeropen.com 